\title{
The Accuracy of Standwise Forest Inventory in Mature Stands
}

\author{
Ainārs Grīnvalds* \\ JSC “Latvijas valsts meži”, Kristapa 30, Rīga, LV-1046, Latvia
}

\begin{abstract}
Traditionally forest resources are estimated in each compartment or stand with ocular standwise forest inventory. However, this inventory technique has shortages with measurement accuracy. In the study the accuracy of the standwise forest inventory was estimated by comparing the growing stock volume of the standwise inventory with the accurate (instrumental) re-measurements. Comparison was done with 4515 mature stands of pine (Pinus sylvestris L.), spruce (Picea abies (L.) Karst.), birch (Betula spp.), aspen (Populus tremula L.) and black alder (Alnus glutinosa L.). The stands' measurements by callipers or by harvesters (recalculated to growing stock volume) were used for accurate re-measurements. The study results show that the volume of standwise forest inventory have relative bias of $17.6 \%$ (volume is underestimated by $17.6 \%$ ) and relative root mean square error $27.5 \%$ for the whole data. Spruce stands are more accurately measured and black alder stands - inaccurately. The accuracy of pine, birch and mixed stands was similar to overall trends. Stands with volume $200-300 \mathrm{~m}^{3} \mathrm{ha}^{-1}$ are more accurately measured and stands with the volume less than $200 \mathrm{~m}^{3} \mathrm{ha}^{-1}$ - most inaccurately. The accuracy of stands with the volume more than $300 \mathrm{~m}^{3} \mathrm{ha}^{-1}$, decreases by increasing the volume of stands. The volume estimation of individual species has different trends in standwise forest inventory. The volume of pine and birch is overestimated and the volume of spruce, aspen and black alder is underestimated.
\end{abstract}

Key words: standwise forest inventory, precise re-measurements, accuracy, bias, relative root mean square error.

\section{Introduction}

The forest resources are estimated in the first step of the forest management planning. The accuracy of estimation has the effect on quality of the forest management planning and the possibility assessment (Bettinger et al., 2009). Traditionally estimation of forest resources is carried out in each compartment or stand with ocular estimation and it is supported by instrumental measurements on typical places of the stand. Standwise forest inventory is the most effective estimation method for forest management planning in the smallest unit - compartment or stand. Nevertheless, the method has shortages with accuracy of measurements. Reasons of inaccuracy are various: stands heterogeneity, surveyors do not visit every part of the compartment and subjectively choose the points of the measurement, inaccurate tables of forest inventory (Koivuniemi and Korhonen, 2006).

The accuracy of the standwise forest inventory has been studied in the number of countries, comparing standwise forest inventory with the accurate measurements. The measurement of accuracy is estimated by systematic error or bias and precision. Bias represents the difference between the average of a set and its true value. Precision represents the variation in a set of repeated measurements of something (West, 2009). Usually, in the similar studies the bias is estimated by relative bias and precision by relative root mean square error (Anttila, 2002, Kinnunen et al., 2003, Koivuniemi and Korhonen, 2006).

In Latvia, in several studies the accuracy of standwise forest inventory was measured. In the studies were found out that the standwise forest inventory stands with less volume are overestimated, but dense, heavily stocked stands are underestimated, as well as the accuracy of the volume evaluation differs by the tree species (Dubrovskis, 2004, Veinbergs, 2007). However, studies were based on a relatively small amount of data. Also in other studies, where the accurate re-measurements of stands were carried out, it was found out that the data of the standwise forest inventory is inaccurate. For example, the accurate measurements of the second storey spruce volume showed that the volume is 2.5 times greater than it was presented in the standwise forest inventory (Zalitis et al., 2013).

The data of the national forest inventory (accurately measured sample plots) was compared with the data of the standwise forest inventory on nationwide level in Lithuania. In the study, it was found out that volume of the standwise forest inventory is underestimated by $16 \%$. Also, reasons for the errors of standwise forest inventory were identified. They are as follows:

\footnotetext{
* Corresponding Author's email:

a.grinvalds@lvm.lv
} 
smaller trees are unmeasured, the second storey is measured incompletely, the stands with larger volume are systematically underestimated, etc. (Kuliešis and Kasperavičus, 2004). A similar study was carried out in the four forest management companies with the aim to assess the accuracy of the standwise forest inventory in the Novgorod region in Russia. The study results show that the volume of the standwise forest inventory is underestimated - the relative bias is $13.4 \%$. Moreover, in the study it was concluded that errors of the standwise forest inventory differ in stands of the dominant tree species and volume groups (Kinnunen et al., 2003). Several studies were realised and similar conclusions were made about the accuracy of standwise forest inventory in Nordic countries. Researchers concluded that the relative bias of standwise forest inventory are in range from 0.8 to $15.4 \%$ of stands volume (Eid, 2000), $15.9 \%$ (Anttila, 2002).

Thereby, the number of studies carried out in Latvia and abroad shows that the standwise forest inventory has inaccurate data. However, realised studies are based on a relatively small amount of data in Latvia. At present, necessary data for assessment of accuracy can be easily obtained from the accurate measurements of roundwood production. The aim of the study is to assess the accuracy of the standwise forest inventory in mature stands by comparing growing stock volume of the stands of dominant trees species, volume groups and each individual species with accurate re-measurements.

\section{Materials and Methods}

The study was realized in the whole territory of Latvia, in the joint stock company's „Latvijas valsts meži" managed forests. The company manages half of Latvia's forests, with total forest area of 1.4 million hectares. The data was collected during the period from the year $2010-2012$. The assessment of accuracy of standwise forest inventory was made in the beginning of the year 2014 .

In the study, the data of 4515 individual stands larger than one hectare was randomly selected from standwise forest inventory data. Sample stands characterise mature pine (Pinus sylvestris L.), spruce (Picea abies (L.) Karst.), birch (Betula spp.), aspen (Populus tremula L.) and black alder (Alnus glutinosa L.) stands with a total forest area of 204 thousands hectares. The sample contains 2054 pine, 391 spruce, 1624 birch, 240 aspen and 201 black alder stands. Stands were selected in the following ages: pine 101 - 130 , spruce $81-110$, birch $71-100$, aspen $41-$ 70 and black alder from $71-100$ years; and in the following site indexes: pine $\mathrm{I}^{\mathrm{a}}-$ III, spruce $\mathrm{I}^{\mathrm{a}}-\mathrm{II}$, birch I ${ }^{\mathrm{a}}-$ III, aspen $\mathrm{I}^{\mathrm{a}}-\mathrm{I}$, black alder I - II.
The growing stock volume of standwise forest inventory and accurate re-measurements was set for each stand. The growing stock volume of standwise forest inventory was selected from the data base of the forest resources. Stands were on the inventory 1 - 10 years ago and stands descriptions were annually updated according to the growth models. The volume of accurate re-measurements was obtained in two ways: from the stands measurements by callipers $(1 / 3$ of the total amount) and from the stands measurements by harvesters (logging and delimbing machines) during logging operations ( $2 / 3$ of total amount). Each tree diameter and height of number of trees was measured in stands measured by callipers. The growing stock volume was calculated based on diameter, height and number of trees, as well as the stem form of each species (Matuzanis, 1988). Data of electronic measurement system of the harvesters was used for stands logged by harvesters. Measurement system of harvester accurately measures and counts the volume of each species roundwood products.

Harvesters' measured volume of roundwood products does not contain volume of bark, tops of the trees etc., so the volume of roundwood products were recalculated to the growing stock volume. For that reason the simple linear regression function was made. 499 mature stands were measured by both methods: by callipers and by harvesters and measurements were used for the regression analysis. Regression function describes each species growing stock volume as a function of the volume of the roundwood products (equation 1).

$$
Y=b \times X,
$$

where:

$Y$ - growing stock volume $-\mathrm{m}^{3} \mathrm{ha}^{-1}$; $X$ - volume of roundwood products $-\mathrm{m}^{3} \mathrm{ha}^{-1}$; $b$ - coefficient.

The accuracy of growing stock volume of standwise forest inventory was estimated and divided into three groups: firstly, for dominant and mixed species stands, secondly, for stands of four volume groups: lower than $200 \mathrm{~m}^{3} \mathrm{ha}^{-1}, 200-300 \mathrm{~m}^{3} \mathrm{ha}^{-1}$, $300-400 \mathrm{~m}^{3} \mathrm{ha}^{-1}$, more than $400 \mathrm{~m}^{3} \mathrm{ha}^{-1}$, thirdly, for each individual species. All three groups were set by data of accurate re-measurements. Accurate re-measurements do not have the volume of first storey. Therefore, the stands of dominant or mixed species were set from the total volume of stand. The tree species dominated if its proportion of volume had more than $50 \%$ of total volume of stand, mixed stands - neither one of the species volume had more than $50 \%$. Totally 1914 pine, 344 spruce, 1274 birch, 
Table 1

The characteristics of regression function for recalculation of the volume of roundwood products to growing stock volume

\begin{tabular}{cccccccc}
\hline Characteristics & Pine & Spruce & Birch & Aspen & $\begin{array}{c}\text { Black } \\
\text { alder }\end{array}$ & Grey alder & $\begin{array}{c}\text { Hard- } \\
\text { woods }\end{array}$ \\
\hline Coefficient b & 1.157 & 1.176 & 1.243 & 1.176 & 1.364 & 1.168 & 1.153 \\
\hline $\begin{array}{c}\text { Coefficient of } \\
\text { determination }\end{array}$ & 0.97 & 0.96 & 0.95 & 0.98 & 0.97 & 0.96 & 0.99 \\
\hline P-value & 0.01 & 0.01 & 0.01 & 0.01 & 0.01 & 0.01 & 0.01 \\
\hline Standard error & 21.7 & 17.5 & 13.9 & 11.9 & 10.4 & 8.3 & 6.2 \\
\hline
\end{tabular}

217 aspen, 160 black alder stands were set as dominant and 608 stands - as mixed. The assessment of accuracy of individual species was done for cases when both samples (standwise forest inventory and accurate re-measurements) have volume.

The assessment of accuracy of standwise forest inventory was made in three steps. Firstly, in each group the descriptive statistics (the average growing stock volume, its standard error and sample mean relative standard error) of the growing stock volume of both data sets (standwise forest inventory and accurate re-measurements) was calculated. Secondly, the t-test was applied to compare between the average growing stock volumes of both data sets whether the differences are significant. Thirdly, the accuracy of the standwise forest inventory was estimated by relative bias (systematic error) and relative root mean square error (variation of errors). Relative bias was measured by equation 2 and relative root means square error (RMSE) was measured by equation 3 .

$$
\begin{aligned}
& B I A S \%=100 \times \frac{\frac{\sum_{i=1}^{n}\left(\hat{y}_{i}-y_{i}\right)}{n}}{\bar{y}}, \\
& R M S E \%=100 \times \frac{\frac{\sqrt{\sum_{i=1}^{n}\left(\hat{y}_{i}-y_{i}\right)^{2}}}{n}}{\bar{y}}
\end{aligned}
$$

where:

$B I A S \%$ - relative bias;

$R M S E \%$ - relative root means square error;

$\hat{\mathrm{y}}_{\mathrm{i}}$ - volume of accurate re-measurement of stand $i$;

$\mathrm{y}_{\mathrm{i}}-$ volume of standwise forest inventory of stand $i$;

$\bar{y}$ - average of volume of precise re-measurements;

$n$ - number of stands.

\section{Results and Discussion}

Firstly, in the study the volume of roundwood products of harvesters' logged stands was recalculated to growing stock volume. Therefore, the linear regression function was made. The coefficient of regression and other characteristics of regression analysis are given in Table 1. The coefficient of determination of the regression function is very high for all species, in the range from $0.95-0.99$. The function significantly $(\mathrm{p}<0.01)$ describes recalculation of the volume of roundwood products to growing stock volume for each species.

The grey alder and hardwoods could be in stands description of other dominant species stands. For that the coefficients of recalculation were made for grey alder and hardwoods, too.

The accuracy of the standwise forest inventory was estimated and placed into three groups: stands of dominant species, stands of volume groups, each individual species (all groups were set by accurate remeasurements). The overall picture of the relationship between growing stock volumes of both samples for whole data is shown in Fig. 1.

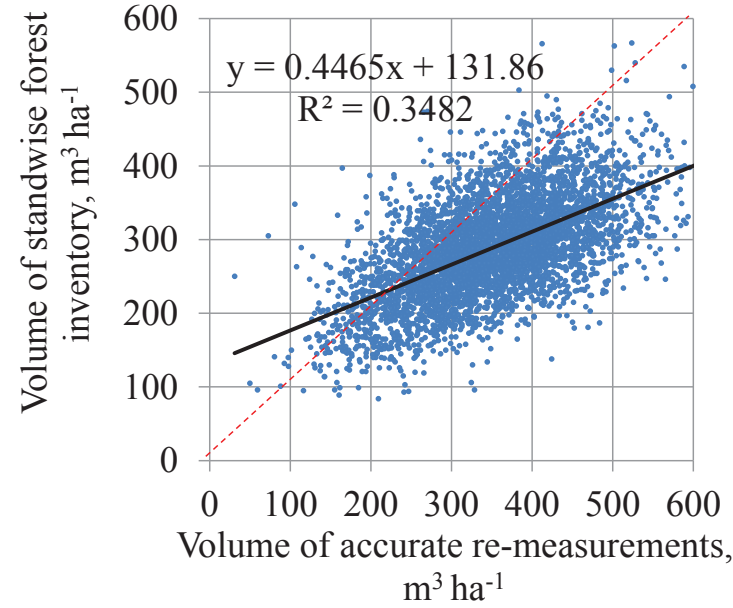

Fig. 1. The relationship between growing stock volume of accurate re-measurements and standwise forest inventory. 
The growing stock volume and its standard error for each group was calculated for both samples: accurate re-measurements and standwise forest inventory (Table 2). The average relative standard error of sample or representativeness for both samples in dominant species stands is in the range of $0.5-1.8 \%$ (excellent), in volume groups is in the range of $0.3-1.9 \%$ (excellent), for each individual species is in the range of $0.7-3.4 \%$ (excellent satisfying). The average growing stock volume differs significantly $(p<0.01)$ between accurate remeasurements and standwise forest inventory in all groups. The accuracy of growing stock volume of standwise forest inventory was measured by relative bias and relative RMSE in each group (Table 2).

The study results show that the volume of standwise forest inventory have relative bias of $17.6 \%$ for the whole data. It means standwise forest inventory underestimates volume by $17.6 \%$. The relative RMSE for the same data is $27.5 \%$. The results of study are similar to other studies in Latvia and its neighbouring countries. The volume of standwise forest inventory on average is underestimated by $16 \%$ in the mature stands of the state forests of Lithuania (Kuliešis and Kasperavičius, 2004) and underestimated by $14.3 \%$ in the mature stands of the state forests of Latvia (Dubrovskis, 2004). The relative bias $13.4 \%$ and relative RMSE $32.4 \%$ was estimated for standwise forest inventory in the Novgorod region in Russia (Kinnunen et al., 2003), the relative bias 15.9\% and relative RMSE 32.8\% was estimated in Finland (Anttila, 2002). Several previous researches in the Nordic countries show that average relative RMSE is approximately $25 \%$ (Koivuniemi and Korhonen, 2006).

The smallest relative bias and relative RMSE have spruce and aspen dominated stands, but the black alders stands have the largest ones. The relative

Table 2

The descriptive statistics of groups' average volume, the relative bias (BIAS\%) and relative root mean square error (RMSE\%) in standwise forest inventory

\begin{tabular}{|c|c|c|c|c|c|}
\hline \multicolumn{2}{|c|}{ Groups } & $\begin{array}{l}\text { Average volume of } \\
\text { ARM }^{*}, \mathrm{~m}^{3} \mathrm{ha}^{-1}\end{array}$ & $\begin{array}{l}\text { Average volume of } \\
\mathrm{SFI}^{* *}, \mathrm{~m}^{3} \mathrm{ha}^{-1}\end{array}$ & BIAS $\%, \%$ & RMSE $\%, \%$ \\
\hline \multirow{7}{*}{$\begin{array}{l}\text { Dominant } \\
\text { species } \\
\text { stands*** }\end{array}$} & pine & $366.3 \pm 2.0$ & $299.8 \pm 1.4$ & 18.2 & 26.3 \\
\hline & spruce & $342.1 \pm 4.4$ & $309.5 \pm 3.2$ & 9.5 & 24.3 \\
\hline & birch & $316.5 \pm 2.4$ & $255.6 \pm 1.9$ & 19.2 & 29.2 \\
\hline & aspen & $385.4 \pm 6.1$ & $341.9 \pm 4.5$ & 11.3 & 24.5 \\
\hline & black alder & $372.5 \pm 6.8$ & $272.9 \pm 4.3$ & 26.7 & 33.9 \\
\hline & mixed & $349.5 \pm 3.5$ & $290.1 \pm 2.5$ & 17.0 & 29.6 \\
\hline & total & $349.3 \pm 1.3$ & $287.8 \pm 1.0$ & 17.6 & 27.5 \\
\hline \multirow{4}{*}{$\begin{array}{c}\text { Volume } \\
\text { groups, } \mathrm{m}^{3} \text { ha }^{-1}\end{array}$} & less than 200 & $166.5 \pm 2.0$ & $198.3 \pm 3.7$ & -19.1 & 39.2 \\
\hline & 200-300 & $260.8 \pm 0.8$ & $247.7 \pm 1.7$ & 3.1 & 21.5 \\
\hline & $300-400$ & $350.3 \pm 0.7$ & $291.3 \pm 1.3$ & 16.1 & 26.2 \\
\hline & more than 400 & $455.1 \pm 1.3$ & $332.7 \pm 1.7$ & 24.4 & 28.6 \\
\hline \multirow{5}{*}{$\begin{array}{l}\text { Individual } \\
\text { species }\end{array}$} & pine & $170.0 \pm 1.9$ & $181.3 \pm 1.9$ & -6.6 & 32.1 \\
\hline & spruce & $142.0 \pm 1.0$ & $83.6 \pm 2.2$ & 41.1 & 54.9 \\
\hline & birch & $96.4 \pm 1.0$ & $113.3 \pm 1.3$ & -17.6 & 49.8 \\
\hline & aspen & $104.3 \pm 2.8$ & $96.8 \pm 2.8$ & 7.2 & 58.5 \\
\hline & black alder & $91.4 \pm 2.9$ & $75.9 \pm 2.6$ & 16.9 & 56.3 \\
\hline
\end{tabular}

*ARM - accurate re-measurements

**SFI - standwise forest inventory

$* * *$ Dominant species - volume $>50 \%$ of total stands volume, in mixed stands no species $>50 \%$ of the total volume 
a)

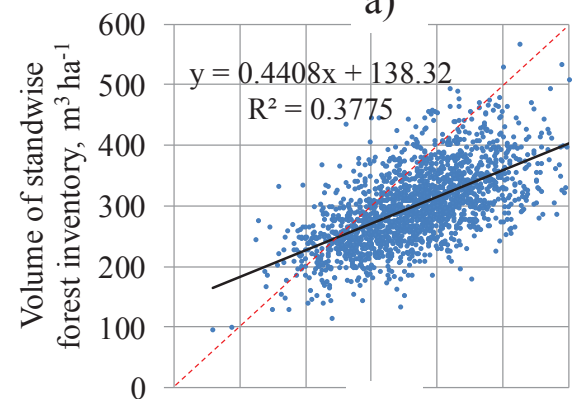

d)

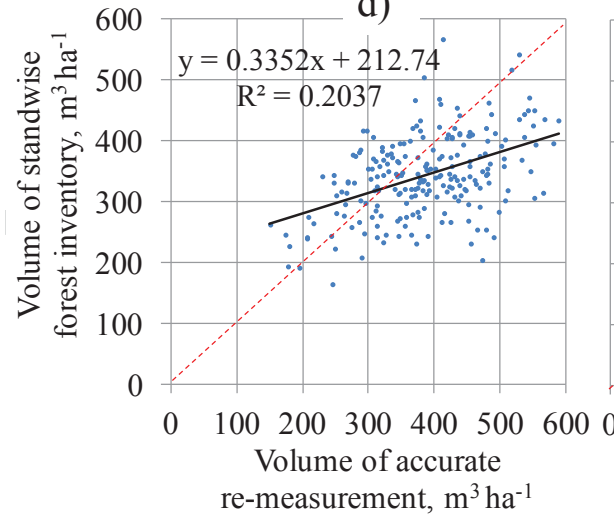

b)

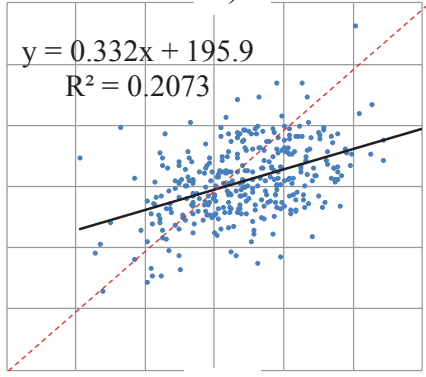

e)

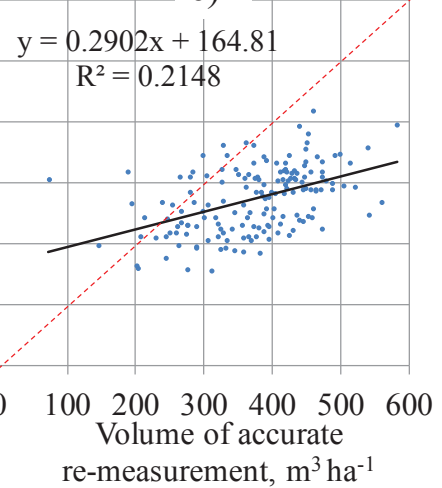

c)

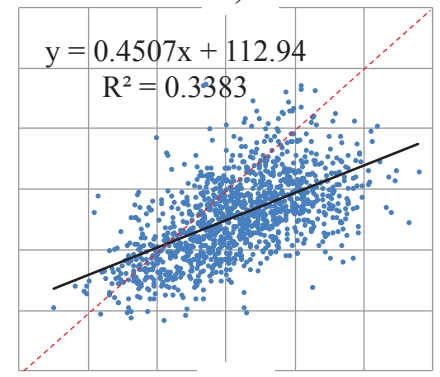

f)

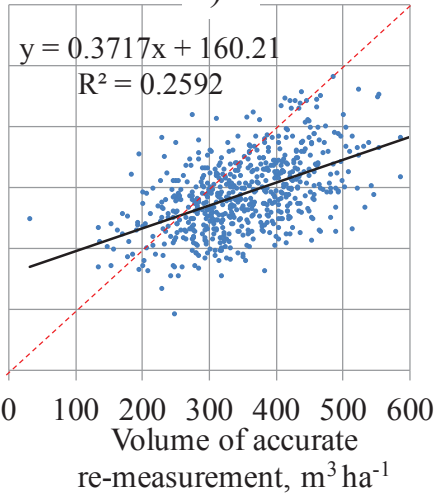

Fig. 2. The relationship between growing stock volume of accurate re-measurements and standwise forest inventory for stands of dominant species: a) pine, b) spruce, c) birch, d) aspen, e) black alder, f) mixed.

bias and relative RMSE was similar to overall trends in pine, birch and mixed stands. These findings are similar to the previous study in Latvia, where it was concluded that volume is underestimated by $17.1 \%$ for pine, $8.9 \%$ for spruce, $13.7 \%$ for birch, $12.1 \%$ for aspen (Dubrovskis, 2004). Different results but with similar trends were obtained in the Novgorod region: $12 \%$ for pine, $-4 \%$ for spruce, $14 \%$ for birch, $21 \%$ for aspen and $16 \%$ for mixed stands (Kinnunen et al., 2003).

The most accurate standwise forest inventory assessment has stands with volume $200-300 \mathrm{~m}^{3} \mathrm{ha}^{-1}$, the relative bias is $3.1 \%$ and relative RMSE is $21.5 \%$. The stands with the volume less than $200 \mathrm{~m}^{3} \mathrm{ha}^{-1}$ have the most inaccurate assessment. These stands are overestimated by $19.1 \%$ and relative RMSE is $39.2 \%$ that is the highest between volume groups. The stands with the volume more than $300 \mathrm{~m}^{3} \mathrm{ha}^{-1}$ show that relative bias and relative RMSE increases with the increasing of stands' volume. The assessment of volume of all dominant species stands have similar trend and follow the overall trend (Figure 2). Similar conclusions are from the study in the Novgorod region. Researchers found out that standwise forest inventory is accurate in the stands with volume of 200 $-300 \mathrm{~m}^{3} \mathrm{ha}^{-1}$, volumes are overestimated in the stands with volume less than $200 \mathrm{~m}^{3} \mathrm{ha}^{-1}$, and underestimated in the stands with volume larger than $300 \mathrm{~m}^{3} \mathrm{ha}^{-1}$
(Kinnunen et al., 2003). The same conclusions were also obtained in the similar study in Latvia. Research shows that the standwise forest inventory is the most accurate in the stands with the volume of $250 \mathrm{~m}^{3} \mathrm{ha}^{-1}$, but stands with larger volume are underestimated (Dubrovskis, 2004).

The measurement accuracy of the volume of each individual species does not have the same trends as the dominant species in standwise forest inventory. The volume of birch and pine is overestimated; volume of spruce, aspen and black alder is underestimated in standwise forest inventory. The largest underestimation has spruce, the largest overestimation has birch. Thus, the volume of individual species has different relative bias (systematic errors). The relative RMSE is in the range of $32.1 \%-56.3 \%$ and for each individual species it is higher than the average of whole data. The partly similar results of systematic errors were obtained in a similar study in Latvia, where it was found out that volume of pine differs by $12.8 \%$, spruce by $33.7 \%$, birch by $-25.5 \%$, aspen by $5.5 \%$ and black alder by $26.8 \%$ (Dubrovskis, 2004).

The trends of volume assessment for individual species are shown in Figure 3. The volume of pine is slightly overestimated at lower volumes and underestimated at larger volumes. The volume of spruce, aspen and black alder is underestimated with the trend: the larger volume has a larger 
a)

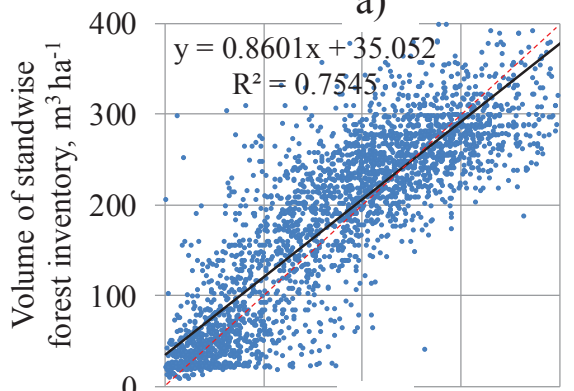

d)

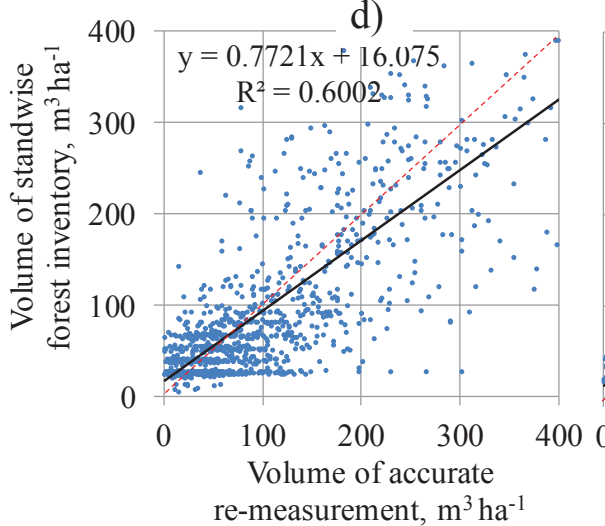

b)

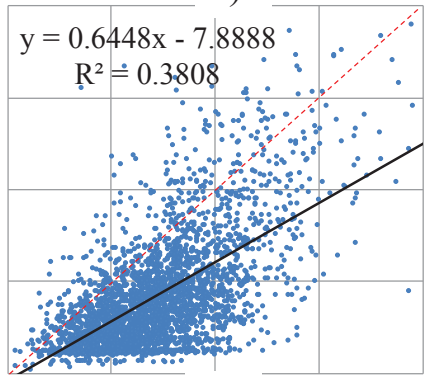

e)

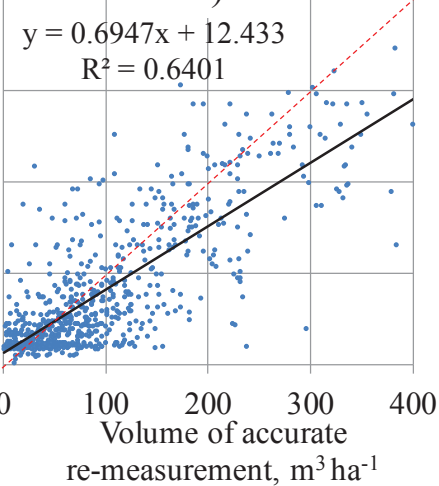

c)

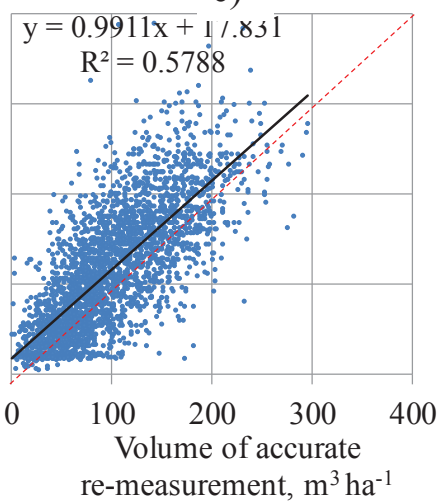

Fig. 3. The relationship between growing stock volume of accurate re-measurements and standwise forest inventory for individual species: a) pine, b) spruce, c) birch, d) aspen, e) black alder.

deviation from the real value. The volume of birch is overestimated with the trend: overestimation is constant at all volumes.

The results of this study are similar to the findings of other studies on accuracy of standwise forest inventory in Lithuania, Russia, Finland, Sweden and Norway. It means that the forest surveyors are measuring the volume with similar errors in standwise forest inventory in all countries, and Latvia is not a unique case.

One of the possible ways how to increase the accuracy of standwise forest inventory is to decrease the systematic errors by calibration. In the simplest way, with regression techniques, the standwise forest inventory estimates achieved by an objective inventory method are predicted as a function of the estimates achieved by the standwise forest inventory method (Koivuniemi and Korhonen, 2006).

\section{Conclusions}

In the study the accuracy of standwise forest inventory was assessed with a large number of accurate re-measurements in mature pine, spruce, birch, aspen, black alder and mixed stands. The study results show that the volume of standwise forest inventory have relative bias of $17.6 \%$ for the whole data. It means that standwise forest inventory underestimates volume by $17.6 \%$. The relative RMSE for the same data is $27.5 \%$. The smallest relative bias and relative RMSE have spruce and aspen dominated stands, but the black alders stands have the largest ones. In pine, birch and mixed stands the relative bias and relative RMSE was similar to overall trends. Stands with the volume $200-300 \mathrm{~m}^{3} \mathrm{ha}^{-1}$ have the most accurate standwise forest inventory assessment, relative bias of those stands is $3.1 \%$ and relative RMSE is $21.5 \%$. Stands with the volume less than $200 \mathrm{~m}^{3} \mathrm{ha}^{-1}$ have the most inaccurate assessment. This stands are overestimated by $19.1 \%$ and relative RMSE is $39.2 \%$. The accuracy of stands with the volume more than $300 \mathrm{~m}^{3} \mathrm{ha}^{-1}$ decreases when the volume of stands increases. The measurement accuracy of the volume of each individual species does not have the same trend, which have stands of the dominant species in standwise forest inventory. The volume of birch and pine is overestimated; the volume of spruce, aspen and black alder is underestimated in the standwise forest inventory. The largest underestimation has spruce, the largest overestimation has birch. The volume of pine is slightly overestimated at lower volumes but underestimated at higher ones. The volume of the spruce, aspen and black alder is underestimated with the trend: larger volumes have larger deviation from the accurate re-measurements. The volume of birch is overestimated with the trend: overestimation is constant at all volumes. 


\section{References}

1. Anttila, P. (2002). Updating stand level inventory data applying growth models and visual interpretation of aerial photographs. Silva Fennica, 36 (2), 549-560.

2. Bettinger, P., Boston, K., Siry, J.P., Grebner, D.L. (2009). Forest management and planning. New York: Academic Press.

3. Dubrovskis, D. (2004). Meža inventarizācijas datu precizitāte, datu izmantošanas iespējas Latvijas meža resursu apsaimniekošanas stratēgijas plānošanā. Pārskats par Meža attīstības fonda pasūtīto pētījumu (The accuracy of forest inventory data, data use options in the forest resource management strategy planning of Latvia. Report of the study of the Forest Development Fund). Salaspils: Latvijas valsts mežzinātnes institūts Silava (In Latvian).

4. Eid, T. (2000). Use of uncertain inventory data in forestry scenario models and consequential incorrect harvest decisions. Silva Fennica, 34 (2), 89-100.

5. Kinnunen, J., Maltamo, M., Pussinen, A. (2003). The Accuracy of Forest Inventory Data in the Novgorod Region in Russia. In Economic Accessibility of Forest Resources in North-West Russia, 4-5 December, 2002, European Forest Institute, 53-62.

6. Koivuniemi, J., Korhonen, K. (2006). Inventory by compartments. In A. Kanngas \& M. Maltamo (Eds.) Forest inventory methodology and applications (pp. 271-278). Dordrecht, Netherlands: Springer.
7. Kuliešis, A., Kasperavičius, A. (2004). Reliability and efficiency of Lithuanian national forest inventory sampling design and results. Baltic Forestry. 10(1), 27-35.

8. Matuzanis, J. (Ed.) (1988) Нормативы для таксации леса Латвийской ССР (The regulations of forest inventory of Latvia), Rīga: Latvijas mežzinātnes institūts Silava (In Russian).

9. Veinbergs, R. (2007). Meža inventarizācijas datu precizitātes novērtējums galvenās cirtes vecumu sasniegušās mežaudzēs valsts mežos (The assessment of accuracy of forest inventory data in mature stands in state managed forests). Master thesis, Latvijas Lauksaimniecības universitāte, Jelgava, Latvija (In Latvian).

10. Zālītis, P., Kalniņa, Ā., Vuguls, J., Zālīte, R., Jansons, J., Zariņa, M. (2013). Bērza audžu ar egles otro stāvu ražības novērtējums un apsaimniekošanas režīms. Valsts pētījumu programmas rakstu krājumā: Vietējo resursu (zemes dzị̂lu, meža, patikas un transporta) ilgtspējīga izmantošana - jauni produkti un tehnologijas 2010 - 2013 (Productivity and management regime of birch stands with spruce understorey. In proceeding: Sustainable Use of Local Resources (Entrails of the Earth, Forest, Food and Transport) - New Products and Technologies 2010-2013), (pp. 77-81). Rīga, Latvija: Koksnes Ķīmijas institūts (In Latvian).

11. West, P.W. (2009). Tree and forest measurement. Berlin: Springer. 